\title{
The molluscan assemblages inhabiting the leaves and rhizomes of a deep water Posidonia oceanica settlement in the central Tyrrhenian Sea
}

\author{
PAOLO G. ALBANO and BRUNO SABELLI \\ Department of Experimental Evolutionary Biology, University of Bologna, Via Selmi, 3, 40126 Bologna, Italy. \\ E-mail: pgalbano@iperbole.bologna.it
}

\begin{abstract}
SUMMARY: The molluscan assemblages inhabiting the leaf and rhizome layers of Posidonia oceanica were studied in a deep water $(-24 / 26 \mathrm{~m})$ settlement of a highly heterogeneous substratum on an off-shore reef in the central Tyrrhenian Sea. This is one of the few works dealing with the rhizome layer and with Posidonia oceanica that has settled on hard substrata. The leaf assemblage only had a few species, less than other assemblages at a comparable depth in the same basin. This poorness may be due to the depth, but it may also be due to the high fragmentation of the meadow. However, the high percentage of carnivores is consistent with previous observations in deep water meadows. The rhizome assemblage is highly diverse both in terms of species and feeding guilds, which could be explained by the higher affinity for low light conditions of most molluscs and the greater habitat heterogeneity. The marked differences in the two taxocoenoses and the high diversification of the rhizome assemblage evidence that they should be included in studies on the potential diversity of Posidonia oceanica meadows. Failure to consider this layer seriously affects any evaluation of the biodiversity of this habitat, which is of great conservation interest.
\end{abstract}

Keywords: Posidonia oceanica, Mollusca, Mediterranean Sea, Secche di Tor Paterno, biodiversity, conservation.

RESUMEN: COMUNIDADES DE MOLUSCOS DE LOS ESTRATOS FOLIARES Y RIZÓMICOS DE UN ASENTAMIENTO PROFUNDO De Posidonia oceanica en el TirReno central. - Las comunidades de moluscos de los estratos foliares y rizómicos de Posidonia oceanica fueron estudiadas en un asentamiento sobre un sustrato altamente heterogéneo de un arrecife costero del mar Tirreno central y de aguas profundas $(-24 / 26 \mathrm{~m})$. Este es uno de los escasos trabajos publicados hasta el momento del asentamiento de Posidonia oceanica sobre sustratos duros y de su correspondiente estrato rizómico. La agrupación de hojas tiene solo unas pocas especies, incluso menos que otras agrupaciones de una profundidad comparable en la misma cuenca. Esta pobreza podría estar causada por la profundidad pero también por la gran fragmentación de la pradera. Por el contrario, el alto porcentaje de carnívoros es consistente con observaciones previas en praderas de aguas profundas. La agrupación de los rizomas es altamente diversa, tanto en términos de especies como de categoría trófica y esto podría ser explicado por la mayor afinidad de la mayoría de los moluscos hacia condiciones de baja luminosidad y la gran heterogeneidad de hábitat. Las marcadas diferencias en las dos taxocenosis y la gran diversificación de las especies del grupo de rizomas aumenta la necesidad de ser incluidos en estudios sobre diversidad potencial de las praderas de Posidonia oceanica. No considerar este estrato afectará seriamente cualquier evaluación de la biodiversidad de este hábitat de gran interés para la conservación.

Palabras clave: Posidonia oceanica, Mollusca, Mediterráneo, Secche di Tor Paterno, biodiversidad, conservación.

\section{INTRODUCTION}

Posidonia oceanica (Linnaeus) Delile is a marine plant endemic to the Mediterranean Sea, where it is distributed quite evenly with the exception of the extreme western part near Gibraltar and the extreme eastern part (Egypt east of the Nile Delta, Palestine, Israel and Lebanon, where it is absent probably due to excessively high temperatures). Moreover, it is not present in the Sea of Marmara or the Black Sea due to their low salinity. Posidonia meadows are one of the most productive ecosystems on Earth. Its production 
has two origins: first, the plant production itself, and second, the production of the leaf epiphytes. Posidonia meadows also play a key role in the oxygenation of the sea water. Posidonia oceanica is considered a key species of the ecosystem and a host to a rich and diversified community. It is estimated that it hosts around 400 plant species and thousands of animal species (Boudouresque et al. 2006), and it is a nursery for several other marine animal species.

For these reasons and also due to the heavy anthropogenic pressure on Mediterranean coastal environments, this habitat is of high conservation interest. As an example, in the Ligurian Sea nearly $30 \%$ of the original meadow surface area was lost during the period of rapid urban and industrial development which occurred in the 1960s along the coast (Bianchi and Morri, 2000). The habitat is considered within the 1120* "Posidonia beds" of the Directive 92/43/ CE "Habitat", and therefore sites hosting Posidonia oceanica can be considered for inclusion in the $\mathrm{Na}-$ tura 2000 network (European Commission - DG Environment 2007). Moreover, this plant is considered endangered and the habitat a priority for conservation by the Protocol Concerning Specially Protected Areas and Biological Diversity in the Mediterranean of the Barcelona Convention.

Posidonia oceanica meadows are very complex habitats. Bianchi et al. (1989) considered it to be composed of four distinct assemblages: the leaf epifauna, the rhizome epifauna, the root-associated sediment infauna and the vagile fauna. Several papers have described the molluscan assemblage inhabiting the leaves, but only a few have described the other assemblages (e.g. Templado 1984, Bonfitto et al. 1998, Solustri et al. 2002, Belgacem et al. 2011; Garcia Raso et al. 1996 which deals with the decapod crustaceans). The plant is found living from a few meters down to $40 \mathrm{~m}$ deep but most papers deal with shallow water meadows inhabiting down to $15 \mathrm{~m}$. A notable exception is the paper by Idato et al. (1983). The authors sampled a Posidonia field from 1 to $30 \mathrm{~m}$ depth and highlighted the variation in the molluscan assemblage composition and structure with depth. They distinguished three main levels: a shallow water level down to $6 \mathrm{~m}$, an intermediate level from 6 to $15 \mathrm{~m}$, and a deep water level below $20 \mathrm{~m}$. No further works have been carried out on the deepest level of Posidonia oceanica fields, and the only other information available on the molluscan assemblages at this depth can be found in Ledoyer (1966).

Posidonia rhizomes can be plagiotropes (spreading horizontally) or orthotropes (spreading vertically) building a complex three-dimensional structure that has a significant sediment component but also a hard component: the rhizomes themselves and their epibiontic species (coralline algae, bryozoans, etc.). The sediment in the rhizomes is of both autochthonous and allochthonous origin. The former is made up of the residuals of organisms which live in the meadows (shells, coralline weeds, etc), the latter consists of sediment which is trapped by the leaves which contribute to reducing the water hydrodynamism. Therefore, rhizomes are a diverse environment which can host species associated with coralline weeds, with hard substrata (the rhizomes themselves) and with soft substrata (the sediment). The complex structure of the rhizome layer is characteristic of this seagrass: the other Mediterranean seagrass species only have horizontal rhizomes (Zostera marina (Linnaeus, 1767), Z. noltii Hornem, 1832) or are smaller (Cymodocea nodosa (Ucria) Ascherson, 1869); hence, they are not able to build up the complex rhizome environment typical of Posidonia oceanica (Borum et al. 2004).

Posidonia rhizomes allow meadows to become established in both soft and hard substrata but very few studies have dealt with this second situation (again Ledoyer 1966; but here only the leaf assemblage is considered).

The aims of this paper were to characterize the composition (qualitative data) and structure (quantitative data) of the molluscan assemblages living both on the leaves and rhizomes of a Posidonia oceanica settlement in deep water $(-24 / 26 \mathrm{~m})$ and in a distinctive environment: an off-shore reef with extensive coralligenous concretions, where the plant lives both in small sedimentary pools and on the hard substratum itself. Among our initial hypotheses, we expected a richer assemblage living in the rhizomes than that living on the leaves, and a leaf-molluscan assemblage with the characteristics of deep water meadows (e.g. high percentage of carnivores).

\section{MATERIALS AND METHODS}

\section{Study area}

The study was carried out in the "Secche di Tor Paterno" marine protected area in the central Tyrrhenian Sea off the coasts of Lazio, south of Lido di Ostia, which is the seaside part of the municipality of Rome (Fig. 1). The reefs are an outcrop of sedimentary Pleistocene rock which lies $12 \mathrm{~km}$ off the coast. The top of the reef is at $18 \mathrm{~m}$, its maximum depth is around 50 $\mathrm{m}$, where a soft substratum is also present. The reef is covered extensively by the coralligenous biocoenosis ("C", Pérès and Picard 1964) but it hosts Posidonia oceanica ("HP", Pérès and Picard 1964) in three different types of settlement: sparse patches, continuous colonization on the hard substratum (the coralligenous formation) and small meadows in the sedimentary pools to a maximum depth of less than $30 \mathrm{~m}$.

Due to the presence of Posidonia oceanica, within the borders of the marine protected area "Secche di Tor Paterno" there is a site of community importance of the Natura 2000 Network (code IT6000010). The site covers 27 hectares and its Posidonia cover is estimated at 5\% (Ministero dell'Ambiente e della Tutela del Territorio 2002). 


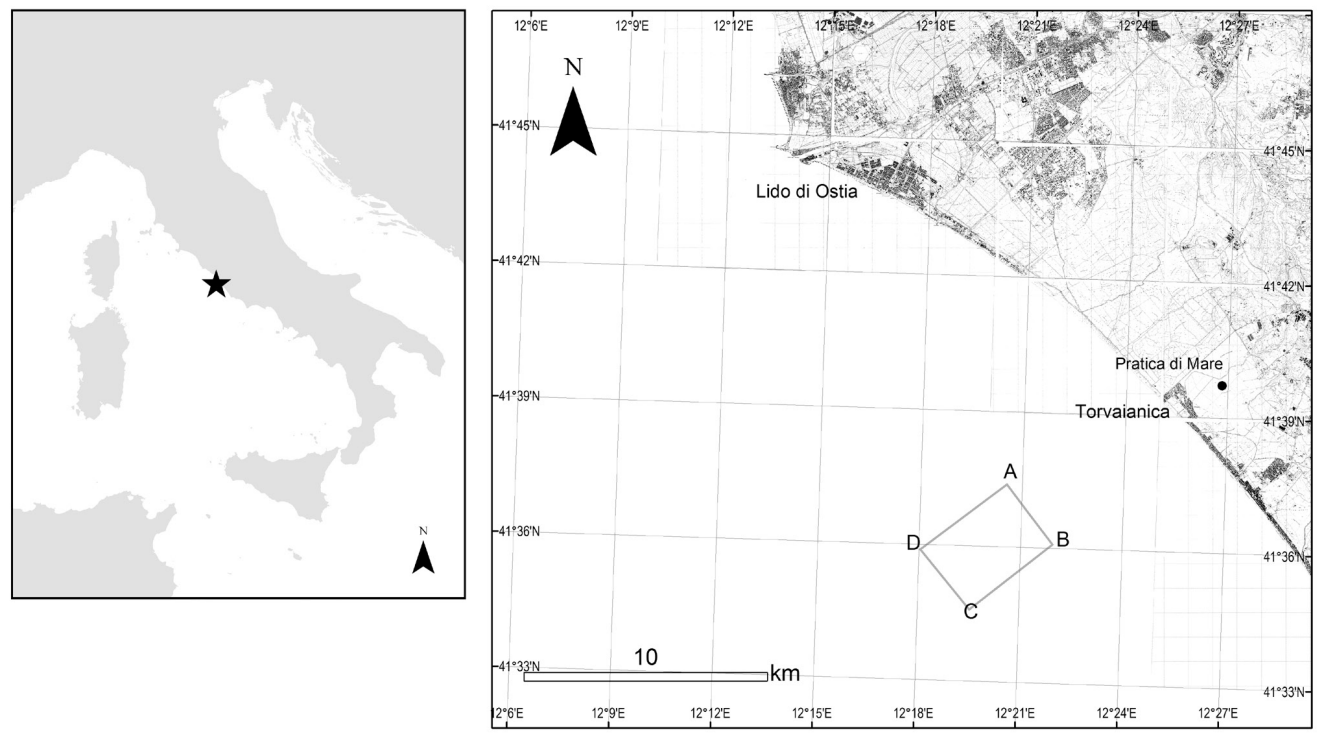

Fig. 1 - Study area; the rectangle A-B-C-D marks the borders of the Marine Protected Area "Secche di Tor Paterno"

\section{Sampling methods}

Samples were collected with two devices: by a standard hand net on the leaves and by an air-lift suction sampler on the rhizomes. Both of these methods were employed by SCUBA divers.

The net was used on Posidonia leaves and was mounted on a metal frame with a $40 \times 20 \mathrm{~cm}$ opening (Buia et al. 2003). Sampling was carried out with net strokes at the base of the leaves to collect the specimens crawling on the leaves. Sampling intensity is quantified by the number of strokes. However, although the standardized method suggested 60 strokes per replicate, we used 20 strokes per replicate due to the small extension of the meadows. These were carried out progressively, advancing into the meadow. However, three replicates for a total of 60 replicates per station were carried out in order to assure comparability with other studies.

The air-lift suction sampler consisted in a PVC tube with a length of $120 \mathrm{~cm}$ and a diameter of $6.5 \mathrm{~cm}$, with a SCUBA cylinder supplying air and fitted at $10 \mathrm{~cm}$ above the mouth of the tube. The other end of the tube was attached to a removable $0.5 \mathrm{~mm}$ mesh nylon bag which could be closed and replaced underwater. Sampling on the rhizomes was carried out on $1 \mathrm{~m}^{2}$ square areas after defoliation in order to enhance collecting efficacy (Bonfitto et al. 1998). Three replicates per station were carried out.

At each site some plant parameters were measured to assess the bed structure and morphometry. The density of the shoots was evaluated by counting shoots on a $0.25 \times 0.25 \mathrm{~m}$ square within each $1 \mathrm{~m}^{2}$ sampled with the air-lift suction sampler. The leaves were counted based on these same shoots and their length measured.

Two sites were chosen to represent differences in the substratum where the Posidonia oceanica settled. At each site the leaves and rhizomes were sampled and represented independent stations. Stations 6 (leaves) and 7 (rhizomes) were located where the Posidonia settled on the coralligenous hard substratum, while stations 8 (leaves) and 9 (rhizomes) were located where the Posidonia settled on the soft substratum. Details about the stations are given in Table 1. First the leaves were sampled and afterwards the area was defoliated to sample the rhizomes independently. Despite care taken in the sampling efficacy of the leaves, a few specimens may have fallen into the rhizomes as the animals retracted in response to the sampling disturbance. Therefore, the fauna of the rhizomes may contain specimens that were crawling on the leaves. A third station was selected at the beginning of the operations on Posido-

TABle 1. - Station list, Marine Protected Area "Secche di Tor Paterno", Central Tyrrhenian Sea, Italy.

\begin{tabular}{|c|c|c|c|c|c|}
\hline Date & 21 May, 2007 & 8 June, 2007 & 20 June, 2007 & 8 June, 2007 & 20 June, 2007 \\
\hline Sampling method & Net & Net & Net & Suction sampler & Suction sampler \\
\hline Depth & $24 \mathrm{~m}$ & $26 \mathrm{~m}$ & $26 \mathrm{~m}$ & $26 \mathrm{~m}$ & $26 \mathrm{~m}$ \\
\hline Habitat details & Posidonia patches & Posidonia patches & Posidonia field & Posidonia patches & Posidonia field \\
\hline & $\begin{array}{l}\text { on hard substratum } \\
\text { - foliar layer }\end{array}$ & $\begin{array}{l}\text { on hard substratum } \\
\text { - foliar layer }\end{array}$ & $\begin{array}{c}\text { on soft substratum } \\
\text { - foliar layer }\end{array}$ & $\begin{array}{c}\text { on hard substratum } \\
\text { - rhizome layer }\end{array}$ & $\begin{array}{c}\text { on soft substratum } \\
\text { - rhizome layer }\end{array}$ \\
\hline Longitude & $12^{\circ} 20^{\prime} 30^{\prime \prime} \mathrm{E}$ & $12^{\circ} 20^{\prime} 28^{\prime \prime} \mathrm{E}$ & $12^{\circ} 20^{\prime} 30^{\prime \prime} \mathrm{E}$ & $12^{\circ} 20^{\prime} 28^{\prime \prime} \mathrm{E}$ & $12^{\circ} 20^{\prime} 30^{\prime \prime} \mathrm{E}$ \\
\hline Latitude & $41^{\circ} 36^{\prime} 13^{\prime \prime} \mathrm{N}$ & $41^{\circ} 36^{\prime} 21^{\prime \prime} \mathrm{N}$ & $41^{\circ} 36^{\prime} 13^{\prime \prime} \mathrm{N}$ & $41^{\circ} 36^{\prime} 21^{\prime \prime} \mathrm{N}$ & $41^{\circ} 36^{\prime} 13^{\prime \prime} \mathrm{N}$ \\
\hline Samples & R1 R2 R3 & R4 R5 R6 & R7 R8 R9 & SP1 SP2 SP3 & SP4 SP5 SP6 \\
\hline Station $n^{\circ}$ & test & 6 & 8 & 7 & 9 \\
\hline
\end{tabular}


nia patches to test the techniques and also to train the diving team (only the leaves were sampled).

The collected samples were sieved in the field with meshes of different sizes (the smallest mesh being 1 $\mathrm{mm}$ ) and were then preserved in $95 \%$ ethanol.

\section{Trophic groups and their feeding guilds}

The following feeding guilds were considered: carnivores (C) feeding on mobile organisms, such as molluscs or polychaetes; scavengers (SC) feeding on remains of dead organisms; deposit feeders (D) feeding on organic particles contained in the sediment; ectoparasites and specialized carnivores (E) feeding on much larger organisms on which they live during their life cycle; filter feeders $(F)$ intercepting nutrient particles with their gills and/or mucous strings; macroalgae grazers (AG); seagrass grazers (SG) ingesting seagrass tissues; microalgal or periphyton grazers (MG) feeding on microalgae (e.g. diatoms); oophagus feeders $(\mathrm{O})$, including species that feed on egg masses of other organisms; and symbiont-bearing species (SY) for those species in which symbiotic bacteria play an important role for obtaining a complementary energy source. Trophic information for all species was obtained from the literature. We used the same classification of feeding modes and guilds used by Rueda et al. (2009) in order to allow comparison.

\section{Data analysis}

Samples were sorted and identified to the species level. The taxonomy follows CLEMAM - Taxonomic Database on European Marine Mollusca" (http://www. somali.asso.fr/clemam/index.php).

Basic diversity indices like the number of specimens $(\mathrm{N})$, the number of species $(\mathrm{S})$, the Shannon index (H', using the loge formula) and Pielou's evenness index $\left(\mathrm{J}^{\prime}\right)$ were calculated. The dominance $(\% \mathrm{D})$ of every species in each sample and the frequency $(\% \mathrm{~F})$ of each species on both the leaves and the rhizomes were also calculated.

Multivariate analyses were implemented in PRIMER-E 6 (Clarke and Gorley 2006). Data were standardized by the total number of specimens in each sample in order to overcome the different sizes of the samples, and square-root transformed to avoid an excessive influence of the most common species since the assemblages were rich and diverse. The Bray-Curtis similarity coefficient was used. Ordination was performed with non-metric multidimensional scaling plots and cluster dendrograms (group average linkage). Statistical tests were performed with ANOSIM (Clarke and Green 1988) and PERMANOVA (Anderson 2001, McArdle and Anderson 2001). In pairwise tests the Bonferroni correction was applied and the proportionately-reduced level of significance was considered. When the number of permutations was too low for meaningful permutation tests, Monte Carlo values of the significance level were considered (Anderson and Robinson 2003). The SIMPER routine (Clarke 1993) was then used to locate which species contribute most to the differences between groups or, conversely, which species contribute most to the similarities within the same group.

The Mann-Whitney U non-parametric test was used to assess the differences in shoot density, mean number of leaves and the mean length of leaves among the studied stations.

\section{RESULTS}

\section{Posidonia oceanica bed structure and morphometry}

At the site of stations 8-9 (soft bottom) the mean shoot density of the meadow was $389 \pm 144$ shoots $/ \mathrm{m}^{2}$, while at the site of stations 6-7 (coralligenous) it was $368 \pm 162$. The high standard deviation may be due to the high environmental heterogeneity of the substratum where the plant has settled. The shoot densities were not significantly different at the two sites (Mann-Whitney, $\mathrm{p}=0.05$ ). The mean number of leaves per shoot at the site of stations 8-9 was 5.8 \pm 2.2 leaves/shoot, while at the site of stations $6-7$ it was $5.4 \pm 1.2$ leaves/shoot; their distributions at the two examined sites differed significantly (Mann-Whitney, $\mathrm{p}=0.05$ ). The mean length of leaves was $434 \pm 204 \mathrm{~mm}$ at the site of stations 6-7, while it was $413 \pm 185 \mathrm{~mm}$ at the site of stations 8-9. Their distributions at the two sites did not differ significantly (Mann-Whitney, $\mathrm{p}=0.05$ ). Data were not collected for the test station on Posidonia patches.

\section{The molluscan taxocoenosis}

Posidonia oceanica leaves and rhizomes host two molluscan taxocoenoses that are remarkably different in terms of richness: the leaves have a poor assemblage composed by 14 species, while the rhizomes host 88 species. Ten of these are common species: Jujubinus exasperatus, Bittium latreillii, Bittium sp. 1, Metaxia metaxae, Cerithiopsis nana, Rissoa violacea, Pusillina inconspicua, Alvania settepassii, Ocinebrina aciculata and Chauvetia mamillata. This means that $71 \%$ of the species living on the leaves are also found on the rhizomes, while only $11 \%$ of the species living on the rhizomes also live on the leaves.

The leaves layer mainly hosts microalgae herbivores and carnivores on mobile prey, while the rhizomes have a much more heterogeneous assemblage of trophic groups with a large presence of filter feeders and ectoparasites and carnivores on preys without mobility (Tables 3 and 4). If the carnivores on every kind of prey are pooled, they dominate the assemblage.

The multivariate analysis of the taxocoenoses living in the two layers of Posidonia oceanica shows that replicates belonging to the two layers cluster together (Fig. 2). In fact, they are two different species assemblages (ANOSIM, $\mathrm{R}=0.782, \mathrm{p}<0.05$ ), and will 
TABle 2. - Faunistic list of molluscs found on the Posidonia leaves with quantitative data. The total number of individuals in each sample, the dominance index $\% \mathrm{D}$ (between brackets), the frequency $\% \mathrm{~F}$ and the feeding guild code are given (C carnivores feeding on mobile organisms; SC scavengers; D deposit feeders; E ectoparasites and specialized carnivores; F filter feeders; AG macroalgae grazers; SG seagrass grazers; MG microalgal or periphyton grazers; O oophagus feeders; SY symbiont-bearing species). Biodiversity indices are reported at the bottom of the table.

\begin{tabular}{|c|c|c|c|c|c|c|c|c|c|c|c|c|}
\hline & & Diet & & Test statio & & & Station 6 & & & Station 8 & & $\% \mathrm{~F}$ \\
\hline & & & $\mathrm{R} 1$ & R2 & R3 & $\mathrm{R} 4$ & R5 & R6 & R7 & R8 & R9 & \\
\hline 1 & Jujubinus exasperatus (Pennant, 1777) & MG & - & - & - & - & - & $1(5 \%)$ & - & - & - & $11.1 \%$ \\
\hline 2 & Calliostoma laugieri (Payraudeau, 1826) & MG & $1(4 \%)$ & - & - & - & - & - & - & - & - & $11.1 \%$ \\
\hline 3 & Cerithium vulgatum Bruguière, 1792 & $\mathrm{MG}$ & $1(4 \%)$ & - & - & - & - & - & - & - & - & $11.1 \%$ \\
\hline 4 & Bittium latreillii (Payraudeau, 1826) & $\mathrm{MG}$ & $20(83 \%)$ & - & $17(68 \%)$ & - & - & $10(53 \%)$ & - & $1(17 \%)$ & - & $44.4 \%$ \\
\hline 5 & Bittium sp. 1 (reticulatum species group) & $\mathrm{MG}$ & - & - & - & - & - & $1(5 \%)$ & - & $2(35 \%)$ & $1(20 \%)$ & $33.3 \%$ \\
\hline 6 & Metaxia metaxae (Delle Chiaje, 1828) & E & - & - & - & - & - & - & - & $1(17 \%)$ & - & $11.1 \%$ \\
\hline 7 & Cerithiopsis nana sensu Auctores non Jeffreys, 1867 & $\mathrm{E}$ & - & - & - & - & $1(33 \%)$ & - & - & - & - & $11.1 \%$ \\
\hline 8 & Rissoa auriscalpium (Linnaeus, 1758) & MG & - & - & $2(8 \%)$ & - & - & - & - & - & - & $11.1 \%$ \\
\hline 9 & Rissoa violacea Desmarest, 1814 & MG & $1(4 \%)$ & $2(33 \%)$ & $1(4 \%)$ & $1(17 \%)$ & - & - & - & $1(17 \%)$ & - & $55.6 \%$ \\
\hline 10 & Pusillina inconspicua (Alder, 1844) & MG & - & - & - & - & - & $1(5 \%)$ & - & - & - & $11.1 \%$ \\
\hline 11 & Pusillina philippi (Aradas and Maggiore, 1844) & MG & - & - & $1(4 \%)$ & - & - & - & - & - & - & $11.1 \%$ \\
\hline 12 & Alvania settepassii Amati and Nofroni, 1985 & MG & - & $1(17 \%)$ & - & - & - & $1(5 \%)$ & - & - & - & $22.2 \%$ \\
\hline 13 & Ocinebrina aciculata (Lamarck, 1822) & $\mathrm{C}$ & - & $3(50 \%)$ & $4(16 \%)$ & - & - & $1(5 \%)$ & - & - & $3(60 \%)$ & $44.4 \%$ \\
\hline 14 & Chauvetia mamillata (Risso, 1826) & $\mathrm{C}$ & $1(4 \%)$ & - & - & $5(83 \%)$ & $2(67 \%)$ & $4(21 \%)$ & - & $1(17 \%)$ & $1(20 \%)$ & $66.7 \%$ \\
\hline & $\mathrm{N}$, number of specimens & & 24 & 6 & 25 & 6 & 3 & 19 & 0 & 6 & 5 & \\
\hline & $\mathrm{S}$, number of species & & 5 & 3 & 5 & 2 & 2 & 7 & 0 & 5 & 3 & \\
\hline & H', Shannon index & & 0.682 & 1.011 & 1.015 & 0.451 & 0.637 & 1.441 & 1.561 & 0.950 & 0.682 & \\
\hline & J', Pielou's evenness & & 0.424 & 0.921 & 0.631 & 0.650 & 0.918 & 0.740 & 0.970 & 0.865 & 0.424 & \\
\hline
\end{tabular}

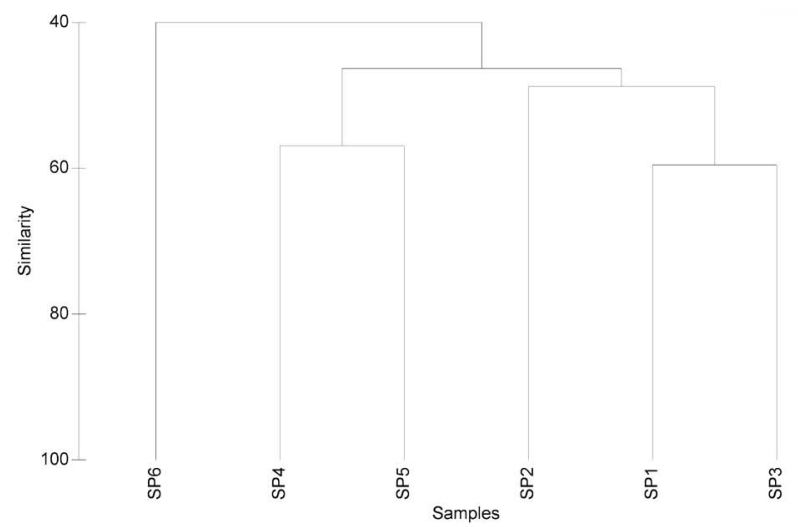

Fig. 2 - Dendrogram for hierarchical clustering of all replicates from the rhizome layer of Posidonia oceanica stations (standardized data, square root transformed data, Bray-Curtis similarity coefficient, group-average linkage)

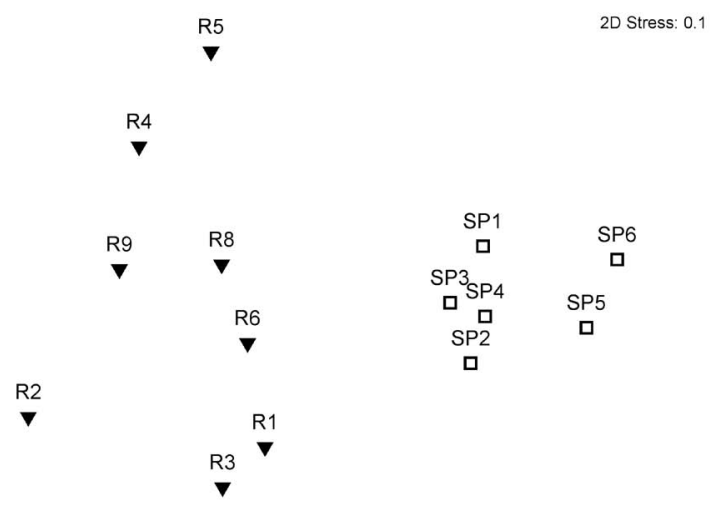

Fig. 3 - Non-metric multi-dimensional scaling plot representing replicates of the Posidonia oceanica leaves (solid triangles) and rhizomes (empty squares) be treated separately in the following paragraphs. The SIMPER routine highlights that differences between leaves and rhizomes originate from the different frequencies of abundant species (Bittium latreillii), the different abundances of species found in both levels (Chauvetia mamillata, Ocinebrina aciculata and Rissoa violacea) and the exclusive presence of species in one of the two levels, mainly on the rhizomes, like $\mathrm{Mu}$ ricopsis cristata, Gouldia minima, Raphitoma linearis, Striarca lactea and Nassarius incrassatus. Moreover, the samples from the rhizomes are more similar to each other (average similarity 46.15) than to the samples from the leaves (average similarity 29.87), which is shown clearly by the non-metric MDS in Figure 3.

\section{The molluscan assemblage on the leaves}

The species collected on the Posidonia leaves and their abundance are given in Table 2. No replicates have any significant differences, nor have the stations (ANOSIM, p>0.05).

From a population structure point of view, species richness in replicates varies from 2 to 7, the Shannon diversity index (H') ranges from 0.451 to 1.441 and the evenness ( $\mathrm{J}$ ') ranges from 0.424 to 0.921 (Table 2 ). The diversity and evenness indices are influenced by dominant species (Table 2, between brackets). The dominant species in replicates R1, R3, R6 and R8 was Bittium latreillii. The dominant species at stations R2 and R9 was Ocinebrina aciculata, while at stations R4 and R5 it was Chauvetia mamillata. The most frequent species are Chauvetia mamillata (present in 6 replicates, 66.7\%), Rissoa violacea (5 replicates, 55.6\%), Bittium latreillii and Ocinebrina aciculata (4 replicates, $44.4 \%)$. Eight species $(57.1 \%)$ are present in a single replicate only. 
TABLE 3. - Number of specimens and species and their percentage for each feeding guild for the Posidonia oceanica leaves.

\begin{tabular}{|c|c|c|c|c|c|c|c|c|c|c|c|}
\hline & & & & Гest station & & & Station 6 & & & Station 8 & \\
\hline & & & R1 & $\mathrm{R} 2$ & R3 & R4 & R5 & R6 & R7 & R8 & R9 \\
\hline $\mathrm{SC}$ & Scavengers & Specimens & - & - & - & - & - & - & - & - & - \\
\hline & & Species & - & - & - & - & - & - & - & - & - \\
\hline AG & Herbivores of macroalgae & Specimens & - & - & - & - & - & - & - & - & - \\
\hline & and epiphytes & Species & - & - & - & - & - & - & - & - & - \\
\hline MG & Microalgae & Specimens & $23(96 \%)$ & $3(50 \%)$ & $21(84 \%)$ & $1(16 \%)$ & - & $14(74 \%)$ & - & $4(66 \%)$ & $1(20 \%)$ \\
\hline & herbivores & Species & $4(80 \%)$ & $2(67 \%)$ & $4(80 \%)$ & $1(50 \%)$ & - & $5(71 \%)$ & - & $3(60 \%)$ & $1(33 \%)$ \\
\hline SG & Seagrass-feeding herbivores & Specimens & - & - & - & - & - & - & - & - & - \\
\hline & & Species & - & - & - & - & - & - & - & - & - \\
\hline D & Deposit feeders & Specimens & - & - & - & - & - & - & - & - & - \\
\hline & & Species & - & - & - & - & - & - & - & - & - \\
\hline $\mathrm{F}$ & Filter feeders & Specimens & - & - & - & - & - & - & - & - & - \\
\hline & & Species & - & - & - & - & - & - & - & - & - \\
\hline SY & Symbiont-bearing species & Specimens & - & - & - & - & - & - & - & - & - \\
\hline & & Species & - & - & - & - & - & - & - & - & - \\
\hline E & Ectoparasites and carnivores & Specimens & - & - & - & - & $1(33 \%)$ & - & - & $1(17 \%)$ & - \\
\hline & on preys without mobility & Species & - & - & - & - & $1(50 \%)$ & - & - & $1(20 \%)$ & - \\
\hline $\mathrm{C}$ & Carnivores on mobile prey & Specimens & $1(4 \%)$ & $3(50 \%)$ & $4(16 \%)$ & $5(83 \%)$ & $2(67 \%)$ & $5(26 \%)$ & - & $1(17 \%)$ & $4(80 \%)$ \\
\hline & & Species & $1(20 \%)$ & $1(33 \%)$ & $1(20 \%)$ & $1(50 \%)$ & $1(50 \%)$ & $2(29 \%)$ & - & $1(20 \%)$ & $2(67 \%)$ \\
\hline $\mathrm{O}$ & Egg and spawn feeders & Specimens & - & - & - & - & - & - & - & - & - \\
\hline & & Species & - & - & - & - & - & - & - & - & - \\
\hline $\begin{array}{l}\text { Carn } \\
\text { herb }\end{array}$ & $\begin{array}{l}\text { nivorous/microalgae } \\
\text { ivores ratio }\end{array}$ & Specimens & 0.0 & 1.0 & 0.2 & 5.0 & 1.0 & 0.4 & - & 0.3 & 4.0 \\
\hline
\end{tabular}

TABLE 4. - Faunistic list of molluscs found on the Posidonia rhizomes with quantitative data. The total number of individuals in each sample, the dominance index $\% \mathrm{D}$ (between brackets), the frequency $\% \mathrm{~F}$ and the feeding guild code are given (C carnivores feeding on mobile organisms; SC scavengers; D deposit feeders; E ectoparasites and specialized carnivores; F filter feeders; AG macroalgae grazers; SG seagrass grazers; MG microalgal or periphyton grazers; O oophagus feeders; SY symbiont-bearing species). Biodiversity indices are reported at the bottom of the table.

\begin{tabular}{|c|c|c|c|c|c|c|c|c|c|}
\hline & & Diet & SP1 & $\begin{array}{c}\text { Station } 7 \\
\text { SP2 }\end{array}$ & SP3 & SP4 & $\begin{array}{c}\text { Station } 9 \\
\text { SP5 }\end{array}$ & SP6 & $\% \mathrm{~F}$ \\
\hline 1 & Hanleya hanleyi (Bean in Thorpe, 1844) & MG & - & - & - & $1(0.7 \%)$ & - & - & $16.7 \%$ \\
\hline 2 & Callochiton septemvalvis (Montagu, 1803) & MG & - & - & - & $1(0.7 \%)$ & - & - & $16.7 \%$ \\
\hline 3 & Chiton corallinus (Risso, 1826) & MG & - & - & $2(2.0 \%)$ & & - & - & $16.7 \%$ \\
\hline 4 & Diodora sp. & $\mathrm{E}$ & - & - & - & $1(0.7 \%)$ & - & - & $16.7 \%$ \\
\hline 5 & Emarginula punctulum Piani, 1980 & E & - & - & - & $1(0.7 \%)$ & - & - & $16.7 \%$ \\
\hline 6 & Emarginula sicula Gray, 1825 & $\mathrm{E}$ & - & - & $1(1.0 \%)$ & - & - & - & $16.7 \%$ \\
\hline 7 & Scissurella costata d'Orbigny, 1824 & MG & - & - & $1(1.0 \%)$ & - & - & - & $16.7 \%$ \\
\hline 8 & Jujubinus exasperatus (Pennant, 1777) & MG & $1(1.4 \%)$ & - & - & $1(0.7 \%)$ & $7(10 \%)$ & - & $50.0 \%$ \\
\hline 9 & Jujubinus striatus (Linnaeus, 1758) & MG & - & - & - & - & - & $1(1.6 \%)$ & $16.7 \%$ \\
\hline 10 & Calliostoma conulus (Linnaeus, 1758) & MG & $1(1.4 \%)$ & - & - & - & - & - & $16.7 \%$ \\
\hline 11 & Bolma rugosa (Linnaeus, 1767) & MG & $1(1.4 \%)$ & - & $1(1.0 \%)$ & $4(2.6 \%)$ & $2(2.9 \%)$ & $2(3.2 \%)$ & $83.3 \%$ \\
\hline 12 & Homalopoma sanguineum (Linnaeus, 1758) & MG & $3(4.1 \%)$ & $6(6.4 \%)$ & $1(1.0 \%)$ & $1(0.7 \%)$ & - & - & $66.7 \%$ \\
\hline 13 & Tricolia tenuis (Michaud, 1829) & MG & - & - & - & $1(0.7 \%)$ & - & $2(3.2 \%)$ & $33.3 \%$ \\
\hline 14 & Smaragdia viridis (Linnaeus, 1758) & SG & - & - & - & - & $1(1.4 \%)$ & $2(3.2 \%)$ & $33.3 \%$ \\
\hline 15 & Bittium latreillii (Payraudeau, 1826) & MG & $6(8.1 \%)$ & $19(20.2 \%)$ & $34(34 \%) 2$ & $20(13.2 \%)$ & $4(5.7 \%)$ & $3(4.8 \%)$ & $100.0 \%$ \\
\hline 16 & Bittium sp. 1 & MG & $1(1.4 \%)$ & $1(1.1 \%)$ & $1(1.0 \%)$ & $3(2 \%)$ & - & - & $66.7 \%$ \\
\hline 17 & Bittium sp. 2 & MG & - & $1(1.1 \%)$ & - & - & - & - & $16.7 \%$ \\
\hline 18 & Turritella turbona Monterosato, 1877 & $\mathrm{~F}$ & - & $1(1.1 \%)$ & - & $4(2.6 \%)$ & $8(11.4 \%)$ & $2(3.2 \%)$ & $66.7 \%$ \\
\hline 19 & Marshallora adversa (Montagu, 1803) & $\mathrm{E}$ & - & $2(2.1 \%)$ & - & $6(3.9 \%)$ & $1(1.4 \%)$ & $1(1.6 \%)$ & $66.7 \%$ \\
\hline 20 & Monophorus erythrosoma (Bouchet and Guillemot, 1978) & E & - & - & $1(1.0 \%)$ & $1(0.7 \%)$ & - & - & $33.3 \%$ \\
\hline 21 & Monophorus perversus (Linnaeus, 1758) & E & - & - & - & - & - & $1(1.6 \%)$ & $16.7 \%$ \\
\hline 22 & Obesula marisnostri Bouchet, 1985 & E & $1(1.4 \%)$ & - & - & - & - & - & $16.7 \%$ \\
\hline 23 & Pogonodon pseudocanaricus (Bouchet, 1985) & E & - & $2(2.1 \%)$ & - & - & - & - & $16.7 \%$ \\
\hline 24 & Metaxia metaxae (Delle Chiaje, 1828) & E & $1(1.4 \%)$ & - & $1(1.0 \%)$ & $3(2 \%)$ & $2(2.9 \%)$ & - & $66.7 \%$ \\
\hline 25 & Cerithiopsis nana sensu Auctores non Jeffreys, 1867 & E & $2(2.7 \%)$ & $1(1.1 \%)$ & $1(1.0 \%)$ & $3(2 \%)$ & - & - & $66.7 \%$ \\
\hline 26 & Cerithiopsis sp. 1 & E & $1(1.4 \%)$ & $2(2.1 \%)$ & $1(1.0 \%)$ & $2(1.3 \%)$ & $1(1.4 \%)$ & - & $83.3 \%$ \\
\hline 27 & Cerithiopsis sp. 2 & E & - & - & - & $1(0.7 \%)$ & - & - & $16.7 \%$ \\
\hline 28 & Cerithiopsis sp. 3 & E & - & $1(1.1 \%)$ & - & - & - & - & $16.7 \%$ \\
\hline 29 & Parvioris ibizenca (Nordsieck, 1968) & E & - & $2(2.1 \%)$ & - & $1(0.7 \%)$ & - & - & $33.3 \%$ \\
\hline 30 & Sticteulima jeffreysiana (Brusina, 1869) & E & - & - & - & $1(0.7 \%)$ & - & - & $16.7 \%$ \\
\hline 31 & Rissoa violacea Desmarest, 1814 & MG & - & - & - & $2(1.3 \%)$ & - & - & $16.7 \%$ \\
\hline 32 & Pusillina inconspicua (Alder, 1844) & MG & $1(1.4 \%)$ & - & - & - & - & - & $16.7 \%$ \\
\hline 33 & Alvania cancellata (da Costa, 1778) & MG & $2(2.7 \%)$ & - & $1(1.0 \%)$ & - & - & - & $33.3 \%$ \\
\hline 34 & Alvania hispidula (Monterosato, 1884) & MG & $2(2.7 \%)$ & - & - & - & - & - & $16.7 \%$ \\
\hline 35 & Alvania settepassii Amati and Nofroni, 1985 & MG & - & - & - & $2(1.3 \%)$ & - & - & $16.7 \%$ \\
\hline 36 & Crepidula sp. & $\mathrm{F}$ & $1(1.4 \%)$ & - & - & - & - & - & $16.7 \%$ \\
\hline 37 & Erosaria spurca (Linnaeus, 1758) & E & - & - & - & $1(0.7 \%)$ & - & - & $16.7 \%$ \\
\hline 38 & Euspira pulchella (Risso, 1826) & $\mathrm{C}$ & - & - & - & $2(1.3 \%)$ & $3(4.3 \%)$ & $1(1.6 \%)$ & $50.0 \%$ \\
\hline 39 & Payraudeautia intricata (Donovan, 1804) & $\mathrm{C}$ & - & - & - & - & $1(1.4 \%)$ & - & $16.7 \%$ \\
\hline
\end{tabular}


TABLE 4 (Cont.). - Faunistic list of molluscs found on the Posidonia rhizomes with quantitative data. The total number of individuals in each sample, the dominance index $\% \mathrm{D}$ (between brackets), the frequency $\% \mathrm{~F}$ and the feeding guild code are given (C carnivores feeding on mobile organisms; SC scavengers; D deposit feeders; E ectoparasites and specialized carnivores; F filter feeders; AG macroalgae grazers; SG seagrass grazers; MG microalgal or periphyton grazers; O oophagus feeders; SY symbiont-bearing species). Biodiversity indices are reported at the bottom of the table.

\begin{tabular}{|c|c|c|c|c|c|c|c|c|c|}
\hline & & Diet & & Station 7 & & & Station 9 & & $\% \mathrm{~F}$ \\
\hline & & & SP1 & SP2 & SP3 & SP4 & SP5 & SP6 & \\
\hline 40 & Dermomurex scalaroides (de Blainville, 1829) & $\mathrm{C}$ & - & - & $2(2.0 \%)$ & - & - & $1(1.6 \%)$ & $33.3 \%$ \\
\hline 41 & Ocinebrina aciculata (Lamarck, 1822) & $\mathrm{C}$ & $3(4.1 \%)$ & $2(2.1 \%)$ & $1(1.0 \%)$ & $5(3.3 \%)$ & $1(1.4 \%)$ & - & $83.3 \%$ \\
\hline 42 & Muricopsis aradasii (Poirier, 1883) & $\mathrm{C}$ & $1(1.4 \%)$ & $1(1.1 \%)$ & $1(1.0 \%)$ & $6(3.9 \%)$ & $2(2.9 \%)$ & $1(1.6 \%)$ & $100.0 \%$ \\
\hline 43 & Muricopsis cristata (Brocchi, 1814) & $\mathrm{C}$ & $8(10.8 \%)$ & $4(4.3 \%)$ & $7(7 \%)$ & $13(8.6 \%)$ & $2(2.9 \%)$ & $6(9.5 \%)$ & $100.0 \%$ \\
\hline 44 & Coralliophila meyendorffii (Calcara, 1845) & $\mathrm{E}$ & - & $1(1.1 \%)$ & - & - & - & - & $16.7 \%$ \\
\hline 45 & Mitra cornicula (Linnaeus, 1758 ) & $\mathrm{C}$ & $1(1.4 \%)$ & - & $1(1.0 \%)$ & - & - & - & $33.3 \%$ \\
\hline 46 & Vexillum ebenus (Lamarck, 1811) & $\mathrm{C}$ & - & - & - & - & - & $1(1.6 \%)$ & $16.7 \%$ \\
\hline 47 & Vexillum savignyi (Payraudeau, 1826) & $\mathrm{C}$ & - & - & - & $1(0.7 \%)$ & $2(2.9 \%)$ & - & $33.3 \%$ \\
\hline 48 & Vexillum tricolor (Gmelin, 1791) & $\mathrm{C}$ & - & $1(1.1 \%)$ & - & $3(2 \%)$ & $2(2.9 \%)$ & - & $50.0 \%$ \\
\hline 49 & Chauvetia mamillata (Risso, 1826) & $\mathrm{C}$ & $5(6.8 \%)$ & $6(6.4 \%)$ & $8(8 \%)$ & $6(3.9 \%)$ & - & $1(1.6 \%)$ & $83.3 \%$ \\
\hline 50 & Chauvetia recondita (Brugnone, 1873) & $\mathrm{C}$ & - & $1(1.1 \%)$ & $2(2.0 \%)$ & $3(2 \%)$ & - & - & $50.0 \%$ \\
\hline 51 & Pollia scabra Locard, 1892 & $\mathrm{C}$ & - & $2(2.1 \%)$ & $5(5 \%)$ & - & - & - & $33.3 \%$ \\
\hline 52 & Nassarius incrassatus (Ström, 1768) & $\mathrm{SC}$ & $5(6.8 \%)$ & $2(2.1 \%)$ & $9(9 \%)$ & $7(4.6 \%)$ & $3(4.3 \%)$ & - & $83.3 \%$ \\
\hline 53 & Mitrella gervillii (Payraudeau, 1826) & $\mathrm{C}$ & - & $1(1.1 \%)$ & - & $1(0.7 \%)$ & - & - & $33.3 \%$ \\
\hline 54 & Mitrella minor (Scacchi, 1836) & $\mathrm{O}$ & - & $2(2.1 \%)$ & - & $3(2 \%)$ & $1(1.4 \%)$ & - & $50.0 \%$ \\
\hline 55 & Mitrella scripta (Linnaeus, 1758) & $\mathrm{C}$ & - & - & - & $1(0.7 \%)$ & $2(2.9 \%)$ & - & $33.3 \%$ \\
\hline 56 & Fusinus pulchellus (Philippi, 1844) & $\mathrm{C}$ & $3(4.1 \%)$ & $3(3.2 \%)$ & $1(1.0 \%)$ & $6(3.9 \%)$ & $2(2.9 \%)$ & $1(1.6 \%)$ & $100.0 \%$ \\
\hline 57 & Mitromorpha karpathoensis (Nordsieck, 1969) & $\mathrm{C}$ & - & $1(1.1 \%)$ & - & - & - & - & $16.7 \%$ \\
\hline 58 & Clathromangelia granum (Philippi, 1844) & $\mathrm{C}$ & $1(1.4 \%)$ & $1(1.1 \%)$ & - & - & - & - & $33.3 \%$ \\
\hline 59 & Mangelia scabrida Monterosato, 1890 & $\mathrm{C}$ & $1(1.4 \%)$ & - & $1(1.0 \%)$ & $1(0.7 \%)$ & $2(2.9 \%)$ & - & $66.7 \%$ \\
\hline 60 & Mangelia stossiciana Brusina, 1869 & $\mathrm{C}$ & - & - & - & $1(0.7 \%)$ & $1(1.4 \%)$ & - & $33.3 \%$ \\
\hline 61 & Raphitoma concinna (Scacchi, 1836) & $\mathrm{C}$ & - & - & - & - & $1(1.4 \%)$ & - & $16.7 \%$ \\
\hline 62 & Raphitoma leufroyi (Michaud, 1828) & $\mathrm{C}$ & - & - & - & $1(0.7 \%)$ & - & - & $16.7 \%$ \\
\hline 63 & Raphitoma linearis (Montagu, 1803) & $\mathrm{C}$ & $4(5.4 \%)$ & $1(1.1 \%)$ & $6(6 \%)$ & $3(2 \%)$ & $1(1.4 \%)$ & $5(7.9 \%)$ & $100.0 \%$ \\
\hline 64 & Raphitoma sp. 1 & $\mathrm{C}$ & $2(2.7 \%)$ & $1(1.1 \%)$ & - & - & - & $1(1.6 \%)$ & $50.0 \%$ \\
\hline 65 & Raphitoma sp. 2 & $\mathrm{C}$ & - & - & - & $1(0.7 \%)$ & - & - & $16.7 \%$ \\
\hline 66 & Raphitoma sp. 4 & $\mathrm{C}$ & - & - & - & $1(0.7 \%)$ & $1(1.4 \%)$ & - & $33.3 \%$ \\
\hline 67 & Mathilda gemmulata Semper, 1865 & $\mathrm{E}$ & - & - & - & $1(0.7 \%)$ & - & - & $16.7 \%$ \\
\hline 68 & Odostomella doliolum (Philippi, 1844) & $\mathrm{E}$ & - & - & $1(1.0 \%)$ & - & - & - & $16.7 \%$ \\
\hline 69 & Ondina sp. & $\mathrm{E}$ & - & - & - & $1(0.7 \%)$ & - & - & $16.7 \%$ \\
\hline 70 & Williamia gussonii (Costa O.G., 1829) & AG & - & - & - & - & - & $1(1.6 \%)$ & $16.7 \%$ \\
\hline 71 & Nucula sp. & $\mathrm{D}$ & $1(1.4 \%)$ & - & - & $1(0.7 \%)$ & - & - & $33.3 \%$ \\
\hline 72 & Barbatia barbata (Linnaeus, 1758) & $\mathrm{F}$ & $1(1.4 \%)$ & $3(3.2 \%)$ & $1(1.0 \%)$ & $2(1.3 \%)$ & - & - & $66.7 \%$ \\
\hline 73 & Striarca lactea (Linnaeus, 1758) & $\mathrm{F}$ & $1(1.4 \%) 1$ & $18(19.1 \%)$ & $1(1.0 \%)$ & $1(0.7 \%)$ & $3(4.3 \%)$ & $2(3.2 \%)$ & $100.0 \%$ \\
\hline 74 & Gregariella semigranata (Reeve, 1858) & $\mathrm{F}$ & $1(1.4 \%)$ & - & - & - & - & $1(1.6 \%)$ & $33.3 \%$ \\
\hline 75 & Dacrydium hyalinum (Monterosato, 1875) & $\mathrm{F}$ & - & - & - & $1(0.7 \%)$ & - & - & $16.7 \%$ \\
\hline 76 & Modiolula phaseolina (Philippi, 1844) & $\mathrm{F}$ & - & $1(1.1 \%)$ & - & $1(0.7 \%)$ & $1(1.4 \%)$ & - & $50.0 \%$ \\
\hline 77 & Lima lima (Linnaeus, 1758) & $\mathrm{F}$ & - & $2(2.1 \%)$ & - & - & - & - & $16.7 \%$ \\
\hline 78 & Kurtiella sp. & $\mathrm{F}$ & $1(1.4 \%)$ & - & - & - & - & - & $16.7 \%$ \\
\hline 79 & Parvicardium scriptum scriptum & & & & & & & & \\
\hline & (Bucquoy, Dautzenberg and Dollfus, 1892) & $\mathrm{F}$ & - & - & $2(2.0 \%)$ & $1(0.7 \%)$ & $1(1.4 \%)$ & $1(1.6 \%)$ & $66.7 \%$ \\
\hline 80 & Papillicardium papillosum (Poli, 1791) & $\mathrm{F}$ & $5(6.8 \%)$ & - & - & $2(1.3 \%)$ & $3(4.3 \%)$ & $10(15.9 \%)$ & $66.7 \%$ \\
\hline 81 & Tellina tenuis da Costa, 1778 & $\mathrm{D}$ & - & - & - & $1(0.7 \%)$ & - & - & $16.7 \%$ \\
\hline 82 & Arcopagia balaustina (Linnaeus, 1758) & $\mathrm{D}$ & - & - & - & - & $1(1.4 \%)$ & $2(3.2 \%)$ & $33.3 \%$ \\
\hline 83 & Gari costulata (Turton, 1822) & $\mathrm{D}$ & - & - & - & - & - & $1(1.6 \%)$ & $16.7 \%$ \\
\hline 84 & Venus verrucosa Linnaeus, 1758 & $\mathrm{~F}$ & $2(2.7 \%)$ & - & - & - & $1(1.4 \%)$ & $2(3.2 \%)$ & $50.0 \%$ \\
\hline 85 & Gouldia minima (Montagu, 1803) & $\mathrm{F}$ & $3(4.1 \%)$ & $1(1.1 \%)$ & $3(3 \%)$ & $10(6.6 \%)$ & $7(10 \%)$ & $10(15.9 \%)$ & $100.0 \%$ \\
\hline 86 & Hiatella arctica (Linnaeus, 1767) & $\mathrm{F}$ & $1(1.4 \%)$ & - & $2(2.0 \%)$ & $1(0.7 \%)$ & - & - & $50.0 \%$ \\
\hline 87 & Thracia distorta (Montagu, 1803) & $\mathrm{F}$ & - & $1(1.1 \%)$ & - & $3(2 \%)$ & - & - & $33.3 \%$ \\
\hline 88 & Antalis vulgaris (da Costa, 1778) & $\mathrm{C}$ & - & - & - & - & - & $1(1.6 \%)$ & $16.7 \%$ \\
\hline & $\mathrm{N}$, number of specimens & & 74 & 94 & 100 & 152 & 70 & 63 & \\
\hline & $\mathrm{S}$, number of species & & 34 & 33 & 30 & 54 & 31 & 27 & \\
\hline & H', Shannon index & & 3.261 & 2.904 & 2.616 & 3.532 & 3.176 & 2.907 & \\
\hline & J', Pielou's evenness & & 0.925 & 0.831 & 0.769 & 0.885 & 0.925 & 0.882 & \\
\hline
\end{tabular}

The analysis of the feeding guilds in terms of specimens for each group (Table 3 ) shows that microalgae herbivores dominate the assemblage in replicates $\mathrm{R} 1$, R3, R6 and R8. In these cases Bittium spp. are the reason for this pattern. The carnivores dominate in replicates R4, R5 and R9. This dominance is demonstrated by two species: Ocinebrina aciculata and Chauvetia mamillata. R2 has an equal number of specimens from the two groups. The ratio between carnivorous and microalgae herbivores ranges from 0 to 5 . It is remarkable that this ratio is equal to or greater than 1 in many samples.

If the analysis is carried out considering the number of species for each feeding guild (Table 3 ), herbivore species dominate in replicates R1, R3, R6 and R8, while carnivore species dominate in replicate R9. However, 
TABLE 5. - Number of specimens and species and their percentage for each feeding guild for the rhizomes.

\begin{tabular}{|c|c|c|c|c|c|c|c|c|}
\hline & & & & Station 7 & & & Station 9 & \\
\hline & & & SP1 & SP2 & SP3 & SP4 & SP5 & SP6 \\
\hline $\mathrm{SC}$ & Scavengers & Specimens & $6.8 \%$ & $2.1 \%$ & $9.0 \%$ & $4.6 \%$ & $4.3 \%$ & - \\
\hline & & Species & $2.9 \%$ & $3.0 \%$ & $3.3 \%$ & $1.9 \%$ & $3.2 \%$ & - \\
\hline $\mathrm{AG}$ & Herbivores of macroalgae and epiphytes & Specimens & - & - & - & - & - & $1.6 \%$ \\
\hline & & Species & - & - & - & - & - & $3.7 \%$ \\
\hline MG & Microalgae herbivores & Specimens & $24.3 \%$ & $28.7 \%$ & $41.0 \%$ & $23.7 \%$ & $18.6 \%$ & $12.7 \%$ \\
\hline & & Species & $26.5 \%$ & $12.1 \%$ & $23.3 \%$ & $18.5 \%$ & $9.7 \%$ & $14.8 \%$ \\
\hline $\mathrm{SG}$ & Seagrass-feeding herbivores & Specimens & - & - & - & - & $1.4 \%$ & $3.2 \%$ \\
\hline & & Species & - & - & - & - & $3.2 \%$ & $3.7 \%$ \\
\hline $\mathrm{D}$ & Deposit feeders & Specimens & $1.4 \%$ & - & - & $1.3 \%$ & $1.4 \%$ & $4.8 \%$ \\
\hline & & Species & $2.9 \%$ & - & - & $3.7 \%$ & $3.2 \%$ & $7.4 \%$ \\
\hline $\mathrm{F}$ & Filter feeders & Specimens & $21.6 \%$ & $28.7 \%$ & $9.0 \%$ & $17.1 \%$ & $34.3 \%$ & $44.4 \%$ \\
\hline & & Species & $26.5 \%$ & $21.2 \%$ & $16.7 \%$ & $18.5 \%$ & $22.6 \%$ & $25.9 \%$ \\
\hline SY & Symbiont-bearing species & Specimens & - & - & - & - & - & - \\
\hline & & Species & - & - & - & - & - & - \\
\hline $\mathrm{E}$ & Ectoparasites and carnivores on preys without mobility & Specimens & $6.8 \%$ & $11.7 \%$ & $6.0 \%$ & $15.1 \%$ & $5.7 \%$ & $3.2 \%$ \\
\hline & & Species & $11.8 \%$ & $21.2 \%$ & $20.0 \%$ & $24.1 \%$ & $9.7 \%$ & $7.4 \%$ \\
\hline $\mathrm{C}$ & Carnivores on mobile prey & Specimens & $39.2 \%$ & $26.6 \%$ & $35.0 \%$ & $36.2 \%$ & $32.9 \%$ & $30.2 \%$ \\
\hline & & Species & $29.4 \%$ & $39.4 \%$ & $36.7 \%$ & $31.5 \%$ & $45.2 \%$ & $37.0 \%$ \\
\hline $\mathrm{O}$ & Egg and spawn feeders & Specimens & - & $2.1 \%$ & - & $2.0 \%$ & $1.4 \%$ & - \\
\hline & & Species & - & $3.0 \%$ & - & $1.9 \%$ & $3.2 \%$ & - \\
\hline Carn & nivorous/ microalgae herbivores ratio & Specimens & 1.6 & 0.9 & 0.9 & 1.5 & 1.8 & 2.4 \\
\hline
\end{tabular}

replicates R4 and R5 have the same number of species from the two groups and herbivores dominate in $\mathrm{R} 2$

\section{The molluscan assemblage on the rhizomes}

The species collected on the Posidonia rhizomes and their abundance are given in Table 5. The Posidonia is settled on different substrata at stations 7 and 9: the coralligenous substratum and the soft sediments respectively. A dendrogram was plotted to test whether there were any differences between these two stations (Fig. 2): it showed that replicates at station 7 (SP1, SP2, SP3) cluster together, replicates SP4 and SP5 at station 9 also cluster together, while replicate SP6 is different from all the others. However, the samples from the two stations are not significantly different (PERMANOVA with Montecarlo simulations due to the low number of samples, $\mathrm{p}>0.05$ ).

To further analyze the pattern described by the dendrogram, the SIMPER routine was run to determine which species contribute to the differences between the two stations. The species which most contribute to the dissimilarity are Papillicardium papillosum, Turritella turbona, Gouldia minima and Euspira pulchella, which are more abundant at station 9. These are all infaunal species found in the sediment where Posidonia settles at station 9, which is a more suitable environment than the hard substratum at station 7. Chauvetia mamillata and Homalopoma sanguineum also contribute to the dissimilarity, as these species were mainly found at station 7 where the Posidonia is settled on a hard substratum. Remarkably, the average similarity within stations is higher at station 7 (52.40) than at station 9 (48.90) despite the hard substratum where the Posidonia is settled. This suggests a more heterogeneous habitat, and therefore less homogene- ity. This is consistent with the cluster dendrogram, and the reason behind this pattern is replicate SP6. The SIMPER routine shows that SP6 is discriminated by a higher proportion of Papillicardium papillosum, Arcopagia balaustina and Venus verrucosa and does not have Nassarius incrassatus and several other rare species like Metaxia metaxae, Mitrella minor, Mitrella scripta, Vexillum tricolor, etc. The presence of more bivalves may indicate a higher proportion of sediment in the sampled site, which is consistent with the lack of the rare species that are more typical of hard substrata.

In terms of population structure, the species richness in the replicates varied from 27 to 54 . The Shannon diversity index $\left(\mathrm{H}^{\prime}\right)$ ranged from 2.616 to 3.532 , and evenness (J') ranged from 0.769 to 0.925 (Table 4). The high values of the Shannon index and the evenness index suggest there are no clearly dominant species. The analysis of species dominance confirms that only Bittium latreillii attained a dominance of $34.0 \%$ in a single sample (SP3), but in the other replicates its dominance decreased to $20.2 \%$ (SP2), $13.2 \%$ (SP4) and below $10 \%$ (SP1, SP5, SP6). B. latreillii is the dominant species in only three replicates. Some filter-feeder bivalves have high dominance values in sample SP6: Papillicardium papillosum and Gouldia minima, both with $15.9 \%$. The predator species Muricopsis cristata is the dominant species in sample SP1 $(10.8 \%)$ and it is also present at a high percentage in samples SP4 (8.6\%) and SP6 $(9.5 \%)$. The most frequent species were Bittium latreillii, Muricopsis aradasii, M. cristata, Fusinus pulchellus, Raphitoma linearis, Striarca lactea and Gouldia minima, which are present in all the replicates. Bolma rugosa, Cerithiopsis sp. 1, Ocinebrina aciculata, Chauvetia mamillata and Nassarius incrassatus were present in five replicates $(83.3 \%) .44 .3 \%$ of species were present in a single replicate only. 
The analysis of feeding guilds in terms of specimens for each group (Table 5) showed a balanced pattern between the most abundant groups: carnivores on mobile prey, microalgae herbivores and filter-feeders. They all have high percentages and are among the dominant groups in all the samples. Filter-feeders are the dominant group in the SP5 and SP6 while microalgae herbivores have a low abundance, confirming that these sites are strongly influenced by a higher percentage of soft substratum. It is important to highlight the high frequency of ectoparasites and carnivores on preys without mobility, which is due to their feeding specialization. They are therefore an important element of the biodiversity of the assemblage, representing up to $24.1 \%$ of the species richness (Table 5). When the two types of carnivores are pooled, they are the dominant group in most samples with the exception of SP6 where the soft substratum conditions lead to a higher proportion of filter feeders.

Scavengers were also present, and constituted up to 9\% of the assemblage (sample SP3). Their presence is scattered and connected to a single species: Nassarius incrassatus. The only egg and spawn feeder species was Mitrella minor and its abundance reached up to $2 \%$. Deposit feeders have a more balanced presence in the samples (they are present in four samples) but with low abundance (from 1.3 to $1.4 \%$ in three samples, while SP6 has $4.8 \%$ due to the soft substratum affinity of this replicate). The presence of macroalgae herbivores (present in two replicates, 3.6\% in SP6, with the species Williamia gussonii) and of seagrass (again present in two replicates up to $3.2 \%$, with the species Smaragdia viridis) is negligible. No symbiontbearing species were found in this environment, which is surprising since these species are infaunal bivalves (Lucinidae, Thyasiridae) for which the sediment enclaves of this biocoenosis would be a suitable habitat. The ratio between carnivores and microalgae feeders is close to or greater than 1 .

\section{DISCUSSION}

\section{Posidonia oceanica bed structure and morphometry}

The density values of Posidonia shoots would be in the third class according to the classification of Giraud (1977), as there is low density meadows with sparse shoots that are associated with this class. Moreover, these meadows are considered to be in regression or in dynamic equilibrium. However, Giraud's classification did not consider the depth factor, which is very important for this plant. For this reason, Pergent et al. (1995) suggested a new classification which considers density and depth. This classification implies that the Posidonia of the Secche di Tor Paterno has a normal density for the depth at which it lives.

Scardi et al. (2005) surveyed the Posidonia in the same area in July 2004 and reported data from a survey carried out in 1998. The data collected in 2004 came from two stations, which are near our station 8 and at a comparable depth: 23 and $25 \mathrm{~m}$. The shoot density was $53.8 \pm 50.3$ and $151.3 \pm 16.2$ shoots $/ \mathrm{m}^{2}$ respectively. Classification according to Giraud was class V and IV respectively, while the evaluation according to Pergent et al. (1995) was a sub-normal density at both stations. The data collected in 1998 did not report station details except for depth, which varied from 22 to $28 \mathrm{~m}$. The shoot density ranged from 155 to 225 shoots $/ \mathrm{m}^{2}$. Classification according to Giraud was class IV and it was "normal density" according to Pergent et al. (1995), with the exception of a single station with sub-normal density.

It is difficult to draw conclusions from these data because it is not known whether samples were taken at the same sites, which is very important due to the heterogeneity of the substratum. However, it seems clear that most samples would classify the meadows at the lower limit of a normal condition or at the upper limit of a sub-normal condition and that this condition has not changed significantly in the considered time-frame. The classification of Pergent et al. (1995) has given the most consistent results throughout the surveys.

\section{The molluscan taxocoenosis}

Pérès and Picard (1964) already highlighted that the Posidonia oceanica meadows cannot be considered a single biocoenosis but are composed of two layers: an upper one on the leaves, photophilous, and a lower one on the rhizomes. In the latter there is low light, and it may host an impoverished coralligenous biocoenosis. It is considered an enclave of the circalittoral level in the infralittoral. When they treated the Posidonia meadows as a biocoenosis (HP) they considered the upper photophilous level of the leaves because it hosts a typical species assemblage. However, Pérès and Picard considered the rhizome community to be strictly related to the coralligenous community, and this approach may have been one of the causes that took attention away from the rhizomes: literature on Posidonia oceanica molluscan taxocoenosis mostly focuses on the leaves.

Bianchi et al. (1989) extended this concept further and suggested that there are four assemblages: the leaf epifauna, the rhizome epifauna, the root-associated sediment infauna and the vagile fauna. The leaves and rhizomes, however, represent a continuum of substratum for those species, like some gastropods, which are mobile and climb up and down the plant axis mainly due to the day-night cycle (nyctohemeral migrations, Russo et al. 1984).

Our data fit this context well: the molluscan assemblages live in the two layer host species assemblages, which are different in terms of species richness and composition. Some species are common to both, but this is due to the nyctohemeral migrations. The trophic group analysis fits the different affinity to the light of the layers. The leaves host a high percentage 
of microalgae herbivores that depend on light for their food availability; they also host a large percentage of mobile carnivores, which is a characteristic of deeper water Posidonia meadows (below $15 \mathrm{~m}$, as evidenced in Idato et al. 1983). The rhizomes host a reduced, but still significant, microalgae herbivore assemblage, but in contrast to the leaves they host a richer and more diversified assemblage of carnivores and an equally important group of filter feeders as well as other lessrepresented feeding guilds. Carnivores and filter feeders do not depend on light for their food intake.

\section{Molluscan assemblage on the leaves}

The leaves only host 14 species. This is an unexpectedly poor assemblage. Idato et al. (1983) found 24 species on Ischia Island at the same depth. Some of the characteristic species (Pérès and Picard 1964) of this community are present, e.g., Rissoa auriscalpium, Rissoa violacea, Bittium latreillii, Ocinebrina aciculata and Chauvetia mamillata. All attain a high frequency with the only exception of $R$. auriscalpium. However, the abundances of some of them are very limited (e.g. $R$. auriscalpium). Idato et al. (1983) observed in Ischia that at this depth the molluscan assemblages have some characteristic species like Gibberula philippi, Granulina marginata (Bivona Ant., 1832) and Flexopecten hyalinus (Poli, 1795), which are absent here. Jujubinus exasperatus is the only species that Idato et al. reported in the deep water assemblage and that is also present here. However, the assemblages of the Secche di Tor Paterno host a few species that in Ischia were found at intermediate $(6-15 \mathrm{~m})$ depths, like Tricolia tenuis, Rissoa violacea, Chauvetia mamillata. A common trait of the two locations is the presence of carnivores that are usually absent from shallower Posidonia meadows. Tricolia tenuis (closely related to $T$. speciosa and $T$. pullus, which are considered characteristic species of this community by Pérès and Picard (1964) and Idato et al. (1983)) and Smaragdia viridis, which is a frequent component of these assemblages, were found on the rhizomes and their absence from the leaves may be due to the nyctohemeral migrations along the plant axis (Russo et al. 1984).

The poorness of this assemblage may be due to several factors. Depth may be one of these, since deep water communities host a reduced number of species with smaller populations compared to the shallower ones (Idato et al. 1983). Moreover, the fragmentation of Posidonia may also negatively influence the size of populations and the recruitment potential. This could be the cause of the rarity of most species: $57.1 \%$ of species are only found in a single replicate. However, the kind of substratum does not seem to influence the foliar layer molluscan assemblage evidenced by the lack of significant differences among stations settled on hard and soft substratums as well as the lack of significant differences in shoot density, which is the main Posidonia bed structure parameter.

\section{Molluscan assemblage of the rhizomes}

Unlike the leaves, the rhizome layer of the Posidonia oceanica meadows and patches hosts a rich and diverse assemblage: 88 species of shelled molluscs were collected. Templado (1984) cited 178 species of molluscs on the rhizomes of Cabo de Palo (southeastern Spain) Posidonia oceanica meadows, but the sampled depth interval was wider (from 1 to $25 \mathrm{~m}$ ) and the meadows were sampled more frequently ( 52 samples covering two years and taken monthly with the only exception of February and March).

Specialized carnivores make a high contribution to the biodiversity of this assemblage. This group accounts for up to $24.1 \%$ of the species richness, and is characterized by taxa such as: Fissurellidae, Triphoridae, Cerithiopsidae, Eulimidae, Pyramidellidae. Triphoridae in particular is represented by six species, a high percentage of the overall infralittoral Mediterranean fauna. Some very rare species are also found in this environment, e.g. Hanleya hanleyi, Obesula marisnostri, Mathilda gemmulata. The low light condition of the rhizomes is similar to the that of the deep water environment where these species are usually found. Two main factors explained the richness of the rhizome layer. The first is the low light habitat, which is the most suitable habitat for most molluscs. Therefore, the greater habitat heterogeneity (hard substratum covered by the coralligenous concretions is intermixed with the pure rhizome habitat) allows a multiplicity of potential niches and interactions, which results in a more complex community.

Pérès and Picard (1964) considered the rhizome layer to be closely related to the coralligenous biocoenosis, for which they list two characteristic species ${ }^{1}$ : Chlamys pes-felis [Manupecten pesfelis (Linnaeus, 1758)] and Lima squamosa [Lima lima (Linnaeus, 1758)]. Neither of these species was frequent in our samples, and in fact only the latter was collected. However, the former was found dead and was also observed living in crevices. This species is hardly ever collected by an air-lift suction sampler due to its size and cryptic habitat. Our sampling is likely to have also intercepted the species living in the upper sediment layer of the seagrass mattes. Harmelin (1964) listed among the characteristic and exclusive molluscan species of this layer: "Venus verrucosa [Linnaeus, 1758], Lima hians [Limaria hians (Gmelin, 1791)], Lima inflata [Limaria tuberculata (Olivi, 1792)], Woodia digitaria [Digitaria digitaria (Linnaeus, 1758)], Lepton squamosum [(Montagu, 1803)], Galeomma turtoni [Sowerby G.B. I in Turton, 1825]". He also cited among the characteristic species that preferentially live in this level: "Cardita trapezia [Glans trapezia (Linnaeus, 1767)], Psammobia vespertina [Gari depressa (Pennant, 1777)]

\footnotetext{
1 In the following species list the original taxa used by Pérès and Picard are retained; however, present day taxa are given between square brackets and the authorship and date of the taxon is
} specified if missing. 
and Tapes pullastra var. geographicus [Venerupis senegalensis (Gmelin, 1791)]". Only Venus verrucosa was found in our samples, although at a low frequency; however, we did not sample the deep mattes, where most of these infaunal species live. Templado (1984) reported Bittium reticulatum (Da Costa, 1778) and Chauvetia minima (Montagu, 1803) (closely related to C. mamillata), Nassarius incrassatus, and Striarca lactea to be among the most frequent species, all of which are also found among the most frequent species in Secche di Tor Paterno. However, all of them can be found in other biocoenoses, and therefore are not characteristic species of the rhizomes.

Habitat heterogeneity is probably the explanation for the diversity of the dominant species, which varied both taxonomically and from a trophic point of view: the $1^{\text {st }}$ and $2^{\text {nd }}$ position in the dominance of each replicate represents eight species and all of the four most common feeding guilds. The habitat heterogeneity is supported by the high percentage of species found in a single replicate only (44.3\%). Although the differences are not statistically significant, the species compositions of the rhizome assemblages settled on hard and soft substrata do show some differences: species typical of soft substrata dominate at station 9, where the Posidonia settles in sediment, such as Turritella turbona, Papillicardium papillosum and Gouldia minima. Species usually associated with hard substrata dominate at station 7, where the Posidonia settles on the coralligenous substrate, such as Bittium latreillii, Muricopsis cristata and Striarca lactea.

Although our data only pertain to Mollusca, which, however, is a highly diverse phyla in this environment, the study results suggest that the rhizome layer of Posidonia oceanica is a very rich habitat that hosts species of deep water affinity, and which deserves more attention and studies in different bathymetric and geographic contexts. Neglecting this layer seriously affects any evaluation of the biodiversity of Posidonia oceanica meadows. The rhizome assemblage is very different from that of the leaves: the different exposure to light and the substratum heterogeneity are the main reasons behind this difference.

\section{ACKNOWLEDGEMENTS}

Sampling was supported by funds of the Ministero dell'Ambiente e Tutela del Territorio e del Mare. Luca Marini, director of the MPA and manager of the managing body RomaNatura, greatly helped in obtaining these funds. Marco Oliverio, Sabrina Macchioni, Letizia Argenti and Roberto Maltini were SCUBA diving buddies during field activities. Francesca Evangelisti, Michela Kuan, Linda Tragni, Francesca Orrù, Maria Teresa Greco helped to sort samples in the laboratory. Elisabetta B. Morello gave suggestions on the statistical treatment of data. Eimi Ailen Font translated the abstract into Spanish. Constantine Mifsud and Paul M. Sammut helped in the preparation of the final ver- sion of the manuscript. Two anonymous referees are acknowledged for their useful comments.

\section{REFERENCES}

Anderson M.J. 2005. PERMANOVA: a FORTRAN computer program for permutational multivariate analysis of variance. Department of Statistics, University of Auckland, New Zealand.

Anderson M.J., Robinson J. 2003. Generalised discriminant analysis based on distances. Australian N Z J Statistics 45: 301-318.

Belgacem W., Langar H., Ben Hassine O.K. 2011. Depth and temporal distribution of vagile fauna associated with Posidonia oceanica meadows in Cap Zebib, north-eastern Tunisian coastline. Afr. J. Ecol. 49: 459-470.

Bianchi C.N., Morri C. 2000. Marine biodiversity of the Mediterranean Sea: situation, problems and prospects for future research. Mar. Pollut. Bull. 40(5): 367-376.

Bianchi C.N., Bedulli D., Morri C., Occhipinti Ambrogi A. 1989. L'herbier de Posidonies: ecosystème ou carrefour écoéthologique? In: Boudouresque C.F., Meinesz A., Fresi E., Gravez V. (eds.), International Workshop Posidonia oceanica Beds, GIS Posidonie, Marseille, pp. 257-272.

Bonfitto A., Fellegara I., Gillone G. 1998. Sampling techniques and structure of the malacofauna associated to the rhizome zone in Posidonia oceanica (L.) Delile. Boll. Malacol. 33 (5-8): 83-88.

Borum J., Duarte C.M., Krause-Jensen D., Greve T.M. 2004. European seagrasses: an introduction to monitoring and management. The M\&MS Project, vii-88 pp.

Boudouresque C.F., Bernard G., Bonhomme P., Charbonnel E., Diviacco G., Meinesz A., Pergent G., Pergent-Martini C., Ruitton S., Tunesi L. 2006. Préservation and conservation des herbiers à Posidonia oceanica. RAMOGE Publ., pp. 1-202.

Buia M.C., Gambi M.C., Dappiano M. 2003. I sistemi a fanerogame marine. In: Gambi M.C., Dappiano M. (eds.), Manuale di metodologie di campionamento e studio del benthos marino mediterraneo. Società Italiana di Biologia Marina 10 (suppl): 145-198.

Clarke K.R. 1993. Non-parametric multivariate analyses of changes in community structure. Aust. J. Ecol. 18: 117-143.

Clarke K.R., Gorley R.N. 2006. PRIMER v6: User manual/Tutorial. PRIMER-E Ltd., Plymouth.

Clarke K.R., Green R.H. 1988. Statistical design and analysis for a 'biological effects' study. Mar. Ecol. Prog. Ser. 46: 213-226.

European Commission - DG Environment 2007. Interpretation manual of European Union habitats - EUR27, 142 pp.

García Raso J.E., López de la Rosa I., Rosales J.M. 1996. Decapod crustacean communities from calcareous seaweed and Posidonia oceanica (rhizome stratum) in shallow waters. Ophelia 45(2): 143-158.

Giraud G. 1977. Essai de classement des herbiers de Posidonia oceanica (Linnaeus) Delile. Bot. Mar. 20(8): 487-491.

Harmelin J. 1964. Etude de l'endofaune des "mattes" d'herbiers de Posidonia oceanica Delile. Recl. Trav. Stn. Mar. Endoume 35(51): 43-105

Idato E., Fresi E., Russo G.F. 1983. Zonazione verticale della fauna vagile di strato foliare in una prateria di Posidonia oceanica Delile: I - Molluschi. Boll. Malacol. 19(5-8): 109-120.

Ledoyer M. 1966. Écologie de la faune vagile des biotopes Méditerranéens accesibles en scaphandre autonome. II. Données analytiques sur les herbiers de phanérogames. Recl. Trav. Stn. Mar. Endoume 41(57): 135-164.

McArdle B.H., Anderson M.J. 2001. Fitting multivariate models to community data: a comment on distance based redundancy analysis. Ecology 82: 290-297.

Ministero dell'Ambiente e della Tutela del Territorio 2002. Natura 2000 data form site IT6000010 "Secche di Tor Paterno".

Pérès J.M., Picard J. 1964. Nouveau Manuel de Bionomie Benthique de la Mer Mediterranée. Recl. Trav. Stn. Mar. Endoume 31(47): 5-137.

Pergent G., Pergent-Martini C., Boudouresque C.-F. 1995. Utilisation de l'herbier a Posidonia oceanica comme indicateur biologique de la qualité du milieu littoral en Méditerranée: état des connaissances. Mésogée 54: 3-27.

Rueda J.L., Gofas S., Urra J., Salas C. 2009. A highly diverse molluscan assemblage associated with eelgrass beds (Zostera marina L.) in the Alboran Sea: micro-habitat preference, feed- 
ing guilds and biogeographical distribution. Sci. Mar. 73(4): $679-700$.

Russo G.F., Fresi E., Vinci D., Chessa L.A. 1984. Mollusk syntaxon of foliar stratum along a depth gradient in a Posidonia oceanica (L.) Delile meadow: diel variability. In: Boudouresque C.F., Jeudy de Grissac A., Olivier J. (eds.), International Workshop on Posidonia oceanica beds. GIS Posidonie publ. 1: 303-310.

Scardi M., Casola E. 2005. Monitoraggio della prateria di Posidonia oceanica. In: Cataudella S. (ed.), Programma di ricerca "Gestione multifunzionale dell'AMP Secche di Tor Paterno". Università di Tor Vergata, Roma, iii-181 pp.
Solustri C., Morello E., Sabelli B. 2002. Primi dati sulla malacofauna associata ad una prateria di Posidonia oceanica (L.) Delile in Adriatico Orientale (Croazia). Biol. Mar. Mediterr. 9: 231.

Templado J. 1984. Moluscos de las praderas de Posidonia oceanica en las costas del Cabo de Palos (Murcia). Invest. Pesq. 48: 509-526.

Scient. ed.: M. Ramón.

Received April 11, 2011. Accepted March 8, 2012.

Published online August 2, 2012. 